\title{
Toxicity of selective insecticides against sap sucking insect pests of cotton (Gossypium hirsutum)
}

\author{
Arzlan Abbas ${ }^{1,2}$, Saddam Hussain ${ }^{2}$, Zhao Xinzi ${ }^{3}$, Wang Ying ${ }^{4}$, Asim \\ Iqbal $^{5}$, Shakil Ahmad ${ }^{6}$, Farman Ullah ${ }^{7}$, Muhammad Usman ${ }^{8}$ and Chen \\ Ri Zhao ${ }^{1 *}$
}

1. Department of Entomology, College of Plant Protection, Jilin Agricultural University, Changchun 130118 PR China

2. Faculty of Agriculture, Department of Entomology, University of Agriculture Faisalabad, 38000, Pakistan

3. Agricultural Mechanization Management Center of Jilin Province, China

4. Lishu experiment station, China Agricultural University, Quanyan gou, lishu, Jilin 136500, China

5. Insect Pest Management Program, Institute of Plant and Environmental Protection, National Agricultural Research Centre, Islamabad, Pakistan

6. School of Plant Protection, Hainan University, Haikou, Hainan Province, 570228, P. R. China

7. Department of Entomology, College of Plant Protection, China Agricultural University, Beijing 100193, China

8. School of Forestry, Beijing Forestry University, Haidian district, 100083, Beijing, China

*Corresponding author's email: rizhaochen@jlau.edu.cn

\section{Citation}

Arzlan Abbas, Saddam Hussain, Zhao Xinzi, Wang Ying, Asim Iqbal, Shakil Ahmad, Farman Ullah, Muhammad Usman and Chen Ri Zhao. Toxicity of selective insecticides against sap sucking insect pests of cotton (Gossypium hirsutum). Pure and Applied Biology. Vol. 11, Issue 1, pp72-78. http://dx.doi.org/10.19045/bspab.2022.110008

\begin{tabular}{llll}
\hline \hline Received: 26/02/2021 & Revised: 23/04/2021 & Accepted: 27/04/2021 & Online First: 17/05/2021 \\
\hline
\end{tabular}

\section{Abstract}

The most devastating cotton crop pests including sucking insect pests like jassid, Amrasca biguttula and aphid, Aphis gossypii. The severe attack of these sucking pests in Pakistan causes yield losses of about 28 percent to the cotton crop. Chemical control such as the use of various insecticides is mainly practiced to minimize yield losses in cotton crops. Here we evaluated the toxicity of some selective insecticides under field conditions to screen out an effective insecticide against these sucking insect pests of cotton. The insecticides tested were imidacloprid $250 \mathrm{ml} /$ acre, acetamiprid $150 \mathrm{ml} / \mathrm{acre}$, nitenpyram $200 \mathrm{ml} /$ acre, movento $250 \mathrm{ml} /$ acre, buprofezin $600 \mathrm{gm} /$ acre and chlorfenapyr $225 \mathrm{ml} /$ acre. The results of this study revealed that all the insecticides tested were effective against $A$. gossypii, after 96 hours of spray, except buprofezin and movento, the other insecticides caused immature and adult mortality. Nitenpyram and buprofezin exhibited the highest mortality rate of adult aphids after $24 \mathrm{~h}$ of spray. When spraying nitenpyram@200ml/acre, acetamiprid@150ml/acre, and imidacloprid@250ml/acre, the highest mortality of A. biguttula adults was recorded after 96 hours of spray. Imidacloprid, acetamiprid, nitenpyram, and buprofezin were statistically equally effective at the immature stage with mortality of A. biguttula after 96 hours of spraying. In addition, acetamiprid and nitenpyram were more effective after 24 hours of spray, but imidacloprid, chlorfenapyr, movento, and buprofezin were less effective and showed low mortality at immature A. biguttula stage.

Keywords: Aphis gossypii; Amrasca biguttula; Insecticides; mortality; neonicotinoids; toxicity

\section{Introduction}

Gossypium hirsutum L. (Cotton) is seen as the bedrock of Pakistan's economy, as it is a major foreign exchange outlet and plays a vital role in the country's financial growth
[1]. There are several reasons for declining cotton yields where insect pests are the major factors causing yield losses of 30$40 \%$ include bollworms and sucking insect pests in Pakistan [2-5], but 28\% yield losses 
are caused by sucking cotton pest attacks [6]. About the appearance of 162 insect species on countless cotton-growing phases $[7,8]$. Cotton insect pests, including jassid, A. biguttula Ishida (Hemiptera, Cicadellidae), an aphid, A. gossypii (Hemiptera: Aphidae), are major insect sucking pests $[1,9]$. The severe attack of these extraction pests causes yellowing of the leaves, which inhibits the plant's development and growth, and ultimately dries up due to cell sap damage [10].

Various management strategies were used $[11,12]$, but chemical insecticides remain essential for insect pest management [1315]. However, the misapplication of chemical insecticides causes hormesis and resistance development in insect pests [1619] and multiple potential side effects on non-target insects (for a review, see ref. 20). Many species of jassid and aphid have been referred to be resistant to pyrethroids [3]. We cause injury by scraping the sap from the leaves beneath the surface. Numerous researchers have performed previous studies on the ability of various pesticides to fight pests [20-29]. In this article, we have compared the effectiveness of various insecticides against sucking cotton insect pests like jassid and aphid.

\section{Materials and Methods}

\section{Description of the study area}

The experiment was conducted on the cotton crop during July 2019 to monitor the toxicity of various insecticides to the cotton jassid (A. biguttula) and aphid (A. gossypii) sucking insect pest under field conditions in Okara District, Tehsil Renala Khurd, Chak 33/1.A.1 Punjab (Pakistan). This experiment was laid out with three replications and six procedures in Randomized Complete Block Design, along with supervision. For each treatment having a row to row distance of $2.5 \mathrm{ft}$ and each plot size was $5 \mathrm{~m} \times 3 \mathrm{~m}$. During thinning, the plant to sector distance was kept at $60-75 \mathrm{~cm}$. Under court, all the agronomic procedures performed were uniform in the entire cotton field. The crop was visited daily to monitor the jassids, aphid population and was sprayed on cotton crop after the output of a sufficient jassids and aphid population.

\section{Insecticides}

Six insecticides were achieved from different sources were used. These were imidacloprid @250ml/acre, acetamiprid @150ml/acre, nitenpyram @200ml/acre, buprofezin@600gm/acre, movento @250ml/acre, and chlorfenapyr @225ml/acre.

\section{Bioassay}

The foliar bioassay was conducted on picked cotton plants. Test solutions were prepared in distilled water at the recommended field doses against jassids and aphids for each of the insecticides mentioned above. The insecticides were applied to the field in the form of a spray using a knapsack hand sprayer with a capacity of 20 liters fitted with a hollow cone nozzle [1]. Pre-treatment data were recorded before spray, and post-treatment data were recorded at 24, 48, 72 and $96 \mathrm{~h}$ intervals to determine the toxicity of the above-listed chemicals. Individuals were declared dead if they are not responsive after being brushed with a camel hair brush or show no movement. The targeted insect pest population was counted at each procedure from 21 randomly selected leaves from one row of the cotton crop. Margin plants are not selected to prevent drift and mitigate boundary impact.

\section{Data analysis}

Corrected percent mortality of each sucking pest in each treatment was calculated using the formula given by Schneider-Orelli's Formula [21], analysis of variance and mean needed to be comparing t- table value at $95 \%$ (1.943). $\mathrm{T} 1=$ Spray with imidacloprid (Confidor 20\% SL) @ 250 ml/acre. T2=Spray with acetamiprid@150 ml/acre. T3= Spray with nitenpyram (Nockout 25 SP) @ 240 gm/acre. T4= Spray with buprofezin@ $600 \mathrm{ml} / \mathrm{acre}$. T5= Spray with movento@250 ml/acre. T6= Spray with chlorfenapyr @ $225 \mathrm{ml} /$ acre. $\mathrm{T} 7=$ control. 


\section{Results}

\section{Aphid, Aphis gossypii}

\section{Adult stage}

After 96 hours of spray, all the insecticides tested caused considerably high mortality to cotton aphid (A. Gossypii) at the adult stage. Total mortality was recorded after 96 hours $98.06 \mathrm{~b}$, which is highly effective at the adult stage against aphid (Table 1). Total mortality-4.16a was observed under field conditions in imidacloprid, after 24 hours. In the case of acetamiprid 54.24a, mortality was recorded after 24 hours as 50 percent mortality was the highest mortality rate. Nitenpyram and buprofezin were highly effective against cotton sucking pest since it causes total mortality after 24 hours (Table 1). Therefore, all of these insecticides tested were statistically equal and highly effective at adult stage with aphid mortality 98.06b (Table 1).

Table 1. Corrected percent mortality of different insecticides for which insects under which conditions are required (Adult aphid)

\begin{tabular}{|c|c|c|c|c|c|c|}
\hline \multirow{2}{*}{ Treatment } & \multirow{2}{*}{$\begin{array}{c}\text { Trade } \\
\text { name }\end{array}$} & Dose & \multicolumn{4}{|c|}{ Population change (- or +) after spray } \\
\cline { 3 - 6 } Common name & Dose/Acre & 24 hours & 48 hours & 72 hours & 96 hours \\
\hline Imidacloprid & Confidor & $250 \mathrm{ml} / \mathrm{acre}$ & $-4.16 \mathrm{a}$ & $88.58 \mathrm{ab}$ & $98.06 \mathrm{~b}$ & $98.06 \mathrm{~b}$ \\
\hline Acetamiprid & Mospilan & $150 \mathrm{ml} / \mathrm{acre}$ & $54.24 \mathrm{a}$ & $98.06 \mathrm{ab}$ & $98.06 \mathrm{~b}$ & $98.06 \mathrm{~b}$ \\
\hline Nitenpyram & Gravitan & $200 \mathrm{ml} / \mathrm{acre}$ & $98.06 \mathrm{a}$ & $98.06 \mathrm{a}$ & $98.06 \mathrm{a}$ & $98.06 \mathrm{a}$ \\
\hline Buprofezin & Corrado & $600 \mathrm{ml} / \mathrm{acre}$ & $98.06 \mathrm{a}$ & $98.06 \mathrm{a}$ & $98.06 \mathrm{a}$ & $98.06 \mathrm{a}$ \\
\hline Spirotetramat & Movento & $250 \mathrm{ml} / \mathrm{acre}$ & $88.30 \mathrm{a}$ & $98.06 \mathrm{ab}$ & $98.06 \mathrm{~b}$ & $98.06 \mathrm{~b}$ \\
\hline Chlorfenapyr & Pirate & $225 \mathrm{ml} / \mathrm{acre}$ & $33.37 \mathrm{a}$ & $98.06 \mathrm{ab}$ & $98.06 \mathrm{~b}$ & $98.06 \mathrm{~b}$ \\
\hline
\end{tabular}

Mean fallowed by the common letter in the respective category are not significantly different from each other and needed to compare at $95 \%$ t- table value (1.943)

\section{Nymph stage}

In Aphis gossypii Movento's immature phase, nitenpyram and imidacloprid caused maximum mortality after 24 hours $91.70 \mathrm{ab}$, 81.70a and 80.48a (Table 2). Movento, nitenpyram, and imidacloprid were highly successful against aphid's nymphal stage. Buprofezin and chlorfenapyr recorded the lowest population after 24 hours, $25.52 \mathrm{a}$ and $32.29 \mathrm{a}$, since they caused 25 to 32 percent mortality and it was considered marginal mortality. The average mortality of all insecticides measured was 98.06b after 96 hours at the immature stage (Table 2).

\section{Jassid, Amrasca biguttula Adult Stage}

The maximum population decline was documented by nitenpyram@200ml / acre in the adult stage of cotton jassid 77.42a after 24 hours, and the minimum mortality in the adult stage of A. biguttula was caused by movento@250ml / acre 26.46a and chlorfenapyr@225ml / acre 26.72a (Table $3)$. Because the effectiveness of these two insecticides was statistically identical after 24 hours of spray. Therefore, after the operation, they induced around 26 percent mortality. After 96 hours, reduction in the population 59.94bc was recorded by movento@250ml / acre (Table 3). After 96 hours, nitenpyram was highly effective against $A$. biguttula and triggered $92.75 \mathrm{bc}$ (Table 3).

\section{Nymph Stage}

In case of immature stage of $A$. biguttula, after 24 hours of spray, maximum population reductions were recorded by nitenpyram and acetamiprid, 66.61a, 60.75a, whereas chlorfenapyr@ $225 \mathrm{ml} /$ acre caused $28.03 \mathrm{a}$ mortality and after 96 hours, it was caused 32.29a mortality. Nitenpyram and acetamiprid were caused highest mortality of $A$. biguttula at immature stage, and after 96 
hours of application $86.04 \mathrm{bc}, 88.07 \mathrm{bc}$ mortality were recorded (Table 4).

Table 2. Corrected percent mortality of different insecticides for which insects under which conditions are required (t-table 1.943) at $95 \%$ (Nymph aphid)

\begin{tabular}{|c|c|c|c|c|c|c|}
\hline \multirow{2}{*}{ Treatment } & \multirow{2}{*}{$\begin{array}{c}\text { Trade } \\
\text { name }\end{array}$} & Dose & \multicolumn{4}{|c|}{ Population change (- or +) after spray } \\
\cline { 3 - 6 } Common name & Dose/Acre & 24 hours & 48 hours & $\mathbf{7 2}$ hours & 96 hours \\
\hline Imidacloprid & Confidor & $250 \mathrm{ml} /$ acre & $80.48 \mathrm{a}$ & $95.93 \mathrm{ab}$ & $98.06 \mathrm{~b}$ & $98.06 \mathrm{~b}$ \\
\hline Acetamiprid & Mospilan & $150 \mathrm{ml} / \mathrm{acre}$ & $75.37 \mathrm{a}$ & $98.06 \mathrm{ab}$ & $98.06 \mathrm{~b}$ & $98.06 \mathrm{~b}$ \\
\hline Nitenpyram & Gravitan & $200 \mathrm{ml} /$ acre & $81.70 \mathrm{a}$ & $98.06 \mathrm{ab}$ & $98.06 \mathrm{~b}$ & $98.06 \mathrm{~b}$ \\
\hline Buprofezin & Corrado & $600 \mathrm{ml} /$ acre & $25.52 \mathrm{a}$ & $39.16 \mathrm{ab}$ & $88.02 \mathrm{bc}$ & $94.58 \mathrm{c}$ \\
\hline Spirotetramat & Movento & $250 \mathrm{ml} / \mathrm{acre}$ & $91.70 \mathrm{ab}$ & $98.06 \mathrm{bc}$ & $79.61 \mathrm{a}$ & $92.22 \mathrm{~b}$ \\
\hline Chlorfenapyr & Pirate & $225 \mathrm{ml} / \mathrm{acre}$ & $32.29 \mathrm{a}$ & $79.09 \mathrm{ab}$ & $89.09 \mathrm{~b}$ & $98.06 \mathrm{bc}$ \\
\hline
\end{tabular}

Mean fallowed by the common letter in the respective category are not significantly different from each other and needed to compare at $95 \% \mathrm{t}$ - table value (1.943)

Table 3. Corrected percent mortality of different insecticides for which insects under which conditions are required (t table 1.943) at $95 \%$ (Jassids adult)

\begin{tabular}{|c|c|c|c|c|c|c|}
\hline Treatment & \multirow{2}{*}{$\begin{array}{c}\text { Trade } \\
\text { name }\end{array}$} & Dose & \multicolumn{4}{|c|}{ Population change (- or +) after spray } \\
\cline { 3 - 7 } Common name & Dose/Acre & 24 hours & 48 hours & 72 hours & 96 hours \\
\hline Imidacloprid & Confidor & $250 \mathrm{ml} / \mathrm{acre}$ & $39.73 \mathrm{a}$ & $73.06 \mathrm{ab}$ & $88.58 \mathrm{~b}$ & $90.47 \mathrm{bc}$ \\
\hline Acetamiprid & Mospilan & $150 \mathrm{ml} / \mathrm{acre}$ & $47.74 \mathrm{a}$ & $78.97 \mathrm{ab}$ & $84.51 \mathrm{~b}$ & $91.28 \mathrm{bc}$ \\
\hline Nitenpyram & Gravitan & $200 \mathrm{ml} / \mathrm{acre}$ & $77.42 \mathrm{a}$ & $85.63 \mathrm{ab}$ & $85.68 \mathrm{~b}$ & $92.75 \mathrm{bc}$ \\
\hline Buprofezin & Corrado & $600 \mathrm{ml} / \mathrm{acre}$ & $34.60 \mathrm{a}$ & $58.70 \mathrm{ab}$ & $80.34 \mathrm{~b}$ & $88.77 \mathrm{bc}$ \\
\hline Spirotetramat & Movento & $250 \mathrm{ml} / \mathrm{acre}$ & $26.46 \mathrm{a}$ & $48.76 \mathrm{ab}$ & $57.98 \mathrm{~b}$ & $59.94 \mathrm{bc}$ \\
\hline Chlorfenapyr & Pirate & $225 \mathrm{ml} / \mathrm{acre}$ & $26.72 \mathrm{a}$ & $71.97 \mathrm{ab}$ & $85.71 \mathrm{~b}$ & $85.71 \mathrm{~b}$ \\
\hline
\end{tabular}

Mean fallowed by the common letter in the respective category are not significantly different from each other and needed to compare at $95 \%$ t- table value (1.943)

Table 4. Corrected percent mortality of different insecticides for which insects under which conditions are required (t-table 1.943) at $95 \%$ (Jassids nymph)

\begin{tabular}{|c|c|c|c|c|c|c|}
\hline Treatment & Trade & Dose & \multicolumn{4}{|c|}{ Population change (- or +) after spray } \\
\cline { 4 - 7 } Common name & name & Dose/Acre & 24 hours & 48 hours & $\mathbf{7 2}$ hours & 96 hours \\
\hline Imidacloprid & Confidor & $250 \mathrm{ml} / \mathrm{acre}$ & $38.82 \mathrm{a}$ & $74.31 \mathrm{ab}$ & $81.55 \mathrm{~b}$ & $82.05 \mathrm{bc}$ \\
\hline Acetamiprid & Mospilan & $150 \mathrm{ml} / \mathrm{acre}$ & $60.75 \mathrm{a}$ & $78.69 \mathrm{ab}$ & $85.55 \mathrm{~b}$ & $88.07 \mathrm{bc}$ \\
\hline Nitenpyram & Gravitan & $200 \mathrm{ml} / \mathrm{acre}$ & $66.61 \mathrm{a}$ & $76.77 \mathrm{ab}$ & $82.83 \mathrm{~b}$ & $86.04 \mathrm{bc}$ \\
\hline Buprofezin & Corrado & $600 \mathrm{ml} / \mathrm{acre}$ & $34.24 \mathrm{a}$ & $49.29 \mathrm{ab}$ & $61.19 \mathrm{~b}$ & $74.57 \mathrm{bc}$ \\
\hline Spirotetramat & Movento & $250 \mathrm{ml} / \mathrm{acre}$ & $36.09 \mathrm{a}$ & $49.28 \mathrm{ab}$ & $51.38 \mathrm{~b}$ & $53.58 \mathrm{bc}$ \\
\hline Chlorfenapyr & Pirate & $225 \mathrm{ml} / \mathrm{acre}$ & $28.03 \mathrm{a}$ & $28.03 \mathrm{a}$ & $-33.37 \mathrm{a}$ & $32.29 \mathrm{a}$ \\
\hline
\end{tabular}

Mean fallowed by the common letter in the respective category are not significantly different from each other and needed to compare at $95 \% \mathrm{t}$ - table value (1.943) 


\section{Discussion}

In this study, we evaluated the effectiveness of various insecticides against the sucking pest of cotton. The findings should be that all the insecticides evaluated were significantly effective against aphids and jassids where high mortalities were reported at different time durations. The insecticides used in our studies, such as nitenpyram and buprofezin, showed high efficiency compared to other insecticides by reducing the increasing aphid population. The results of our present study are consistent with those of $[30,31]$, where they documented the sublethal effects of nitenpyram's short-term and chronic exposure to the cotton aphid A. gossypii. Our results showed that nitenpyram directly exposed to even low doses caused sublethal effects on the reproduction and longevity of the aphids. Our findings are also in line with [32], where they studied novel insecticide potency with an accelerated inhibitory effect on aphid feeding. Their results showed strong and rapid toxicity of the novel insecticide flonicamid against various aphid species, Myzus persicae, A. gossypii, Erysimi rhopalosiphum, and Graminum schizaphis. [33] studied buprofezin 25 EC 's comparative bioefficacy against sucking cotton bugs, and its immunity to natural enemies. Their results indicated that buprofezin was highly effective against the cotton sucking pest $A$. gossypii and had no adverse effects on the population of natural enemies. Buprofezin, is an inhibitor of chitin synthesis that can combat hemipteran pests, especially melon aphid, A. gossypii. Buprofezin should influence the biological characteristics by decreasing the chitin content due to the inhibition of chitin synthase activity in the subsequent melon aphid generation [34]. Concerning jassids, all our results are consistent with previously reported results from [1, 21, 35-40]. They have also confirmed that neo-nicotinoids, i.e., nitenpyram and imidacloprid, effectively reduce the population. In addition, [41] reported that after seven days of application, nitenpyram and acephate reduced the jassids population below ETL. Whereas [42] observed that nitenpyram reduced Jassids population significantly over 14 days. All the results discussed above suggested that all the insecticides used in this experiment showed efficiency in managing cotton sucking pests, i.e., aphids and jassids. Nitenpyram, acetamiprid, and buprofezin could be found among the insecticides tested in our study as potential candidate insecticides for the management of $A$. gossypii and A. biguttula in cotton crops due to their greater efficacy and lower toxicity to natural enemies associated with them. Our present study has provided a theoretical basement for insecticides in cotton crops under IPM to control sucking pests.

\section{Conclusion}

The present study concluded that among different tested insecticides, nitenpyram, acetamiprid, and buprofezin were the most effective insecticides for nymphal and adult stages of $A$. gossypii and A. biguttula in cotton crops under field conditions. This study provided a theoretical basis for the use of effective insecticides against sucking insect pests of cotton.

\section{Authors' contributions}

Conceived and designed the experiment: A Abbas, S Hussain \& C Ri-zhao, Performed the experiment: S Hussain \& A Abbas, Analyzed the data: Z Xinzi, W Ying, S Ahmad \& M Usman, Contributed materials/ analysis/ tools: A Abbas, S Hussain \& C Ri-zhao, Wrote and revised the manuscript: A Iqbal, A Abbas \& F Ullah.

\section{Acknowledgments}

I would like to pay thanks to the Government of Jilin Province for funding under the Jilin Government Fund on ACB Control (20150101073JC) and Under the Ministry of Science and Technology of China (2017YFD0201804-5).

\section{References}

1. Asi MR, Afzal M, Anwar SA \& Bashir MH (2008). Comparative Efficacy of Insecticides Against Sucking Insect Pests 
of Cotton. Pak J Life Soc Sci 6: 140-142.

2. Haque H (1972). Cotton Entomology: in Pakistan. Pakistan Cent Cotton Comm Karachi 183-238.

3. Ahmad M, Arif MI \& Ahmad Z (1999). Detection of resistance to pyrethroids in field populations of cotton jassid (Homoptera: Cicadellidae) from Pakistan. J Econ Entomol 92: 1246-1250.

4. Muhammad A \& Anjum S (2010). Studying the sucking insect pests community in transgenic Bt cotton. Int $J$ Agric Biol 12: 764-768.

5. Asif MU, Muhammad R, Akbar W \& Tofique M (2016). Relative efficacy of some insecticides against the sucking insect pest complex of cotton. Nucl 53: 140-146.

6. Chavan SJ, Bhosle BB \& Bhute NK (2010). Estimation of losses due to major insect-pests in desi cotton (Gossypium arboreum L.) in Maharashtra. J Cott Res Dev 24: 95-96.

7. Kannan M, Uthamasamy S \& Mohan S (2004). Impact of insecticides on sucking pests and natural enemy complex of transgenic cotton. Curr Sci 726-729.

8. Abbas N, Shad SA \& Razaq M (2012). Fitness cost, cross resistance and realized heritability of resistance to imidacloprid in Spodoptera litura (Lepidoptera: Noctuidae). Pestic Biochem Physiol 103: 181-188.

9. Razaq M, Suhail A, Aslam M, Arif MJ, Saleem MA \& Khan MHA (2005). Evaluation of neonicotinoids and conventional insecticides against cotton jassid, Amrasca devastans (Dist.) and cotton whitefly, Bemisia tabaci (Genn.) on cotton. Pak Entomol 27: 75-78.

10. Hullé M, Chaubet B, Turpeau E, Simon JC (2020). Encyclop'Aphid: a website on aphids and their natural enemies. Entomol Gen 40(1): 97-101.

11. Tariq K, Ali A, Davies TGE, Naz E, Naz L, et al. (2019). RNA interferencemediated knockdown of voltage-gated sodium channel (MpNav) gene causes mortality in peach-potato aphid, Myzus persicae. Sci Rep 9: 52-91.

12. Ullah F, Gul H, Wang X, Ding Q, Said F, et al. (2020). RNAi-Mediated Knockdown of Chitin Synthase 1 (CHS1) Gene Causes Mortality and Decreased Longevity and
Fecundity in Aphis gossypii. Insects 11: 22.

13. Abbas A, Wang Y, Muhammad U, Fatima A, et al. (2021). Efficacy of different insecticides against gram pod borer (Helicoverpa armigera) and their safety to the beneficial fauna. Int J Biosci 18: 8288.

14. Ullah F, Gul H, Desneux N, Tariq K, Ali A, et al. (2019). Clothianidin-induced sublethal effects and expression changes of vitellogenin and ecdysone receptors genes in the melon aphid, Aphis gossypii. Entomol Gen 39: 137-149.

15. Ullah F, Gul H, Yousaf HK, Xiu W, Qian $\mathrm{D}$, et al. (2019). Impact of low lethal concentrations of buprofezin on biological traits and expression profile of chitin synthase 1 gene (CHS1) in melon aphid, Aphis gossypii. Sci Rep 9: 12291.

16. Gul H, Ullah F, Biondi A, Desneux N, Qian D, et al. (2019). Resistance against clothianidin and associated fitness costs in the chive maggot, Bradysia odoriphaga. Entomol Gen 39: 81-92.

17. Ullah F, Gul H, Tariq K, Desneux N, Gao $X$, et al. (2020). Functional analysis of cytochrome P450 genes linked with acetamiprid resistance in melon aphid, Aphis gossypii. Pestic Biochem Physiol Pestic Biochem Physiol 175: 104687.

18. Ullah F, Gul H, Tariq K, Desneux N, Gao $X$, et al. (2020). Acetamiprid resistance and fitness costs of melon aphid, Aphis gossypii: An age-stage, two-sex life table study. Pestic Biochem Physiol: 104729.

19. Ullah F, Gul H, Tariq K, Desneux N, Gao $X$, et al. (2020). Thiamethoxam induces transgenerational hormesis effects and alteration of genes expression in Aphis gossypii. Pestic Biochem Physiol 165: 104557.

20. Desneux N, Decourtye A, Delpuech JM (2007). The sublethal effects of pesticides on beneficial arthropods. Annu Rev Entomol 52: 81-106.

21. Abbas A, Saddam H, Asim I, Muhammad A, Amir S, et al. (2020). Seed treatment of Capsicum annuum with two different fungicides to evaluate the seed germination rate. J Biol Agri Healthcare 10: 4.

22. Tufail M, Mahmood RZ \& Razaq A (1995). The comparative efficacy of some latest spray-schedules of cotton variety 
FH-682. Pak Entomol 17: 117-119.

23. Attique MR \& Ghaffar A (1996). Control of season sucking pests of cotton with seed protectant insecticides and the their impact on natural enemies and yield of seed cotton. Pak J Zool 28: 253-256.

24. Wahla MA, Tufail M \& Iqbal P (1997). The comparative effectiveness of different doses of Confidor 200SL and Tamaron 600SL against cotton thrips, Thrips tabaci Lind. on FH-582, cotton. Pak Entomol 19: 8-10.

25. Natwick ET (1999). New insecticides for control of silver leaf whitefly: An efficient evaluation. In Proceedings of the Proc. Belt-wide Cotton Conferences. National Cotton Council, Memphis TN. USA 2: 910-920.

26. Saleem MA, Mustafa K \& Hussain R (2001). Comparative efficacy of some insecticides against some sucking insect pests of CIM-443 cotton. Pak Entomol 23: 91-92.

27. Aslam M, Razaq M, Shah SA \& Ahmad F (2004). Comparative efficacy of different insecticides against sucking pests of cotton. J Res Sci 15: 53-58.

28. Shah MJ, Ahmad A, Hussain M, Yousaf MM \& Ahmad B (2007). Efficiency of different insecticides against sucking insect-pest complex and effect on the growth and yield of mungbean (Vigna radiata L.). Pak Entomol 29: 83-85.

29. Khattak MK, Mamoon-ur-Rashid SAS \& Islam HT (2006). Comparative effect of neem (Azadirachta indica A. Juss) oil, neem seed water extract and Baythroid TM against whitefly, jassids and thrips on cotton. Detail 1, T7.

30. Püntener W (1981). Manual for field trials in plant protection; Ciba-Geigy.

31. Wang S, Qi Y, Desneux N, Shi X, Biondi A \& Gao X (2017). Sublethal and transgenerational effects of short-term and chronic exposures to the neonicotinoid nitenpyram on the cotton aphid Aphis gossypii. J Pest Sci 90: 389-396.

32. Morita M, Ueda T, Yoneda T, Koyanagi T \& Haga T (2007). Flonicamid, a novel insecticide with a rapid inhibitory effect on aphid feeding. Pest Manag Sci Former Pestic Sci 63: 969-973.

33. Sontakke BK, Mohapatra LN \& Swain LK (2013). Comparative bioefficacy of
Buprofezin $25 \mathrm{EC}$ against sucking pests of cotton and its safety to natural enemies. Ind J Entomol 75: 325-329.

34. Ullah F, Gul H, Yousaf HK, Xiu W, Qian D, Gao X, Tariq K, Han P, Desneux N \& Song D (2019). Impact of low lethal concentrations of buprofezin on biological traits and expression profile of chitin synthase 1 gene (CHS1) in melon aphid, Aphis gossypii. Sci Rep 9: 1-13.

35. Yazdani MS, Sohail A, Razaq M \& Khan HA (2000). Comparative efficacy of some insecticides against cotton Jassids, (Amrasca devastans Dist.) and their on effect non-target insects in cotton. Intl $J$ Agric Biol 2: 19-20.

36. Khattak MK, Ali S, Chishti JI, Saljiki AR \& Hussain AS (2004). Efficacy of certain insecticides against some sucking insect pests of mungbean (Vigna radiata L.). Pak Entomol 26: 75-80.

37. Raghuraman M \& Gupta GP (2006). Effect of neonicotinoids on jassid, Amrasca devastans (Ishida) in cotton. Ann Plant Prot Sci 14: 17-21.

38. Awan DA \& Saleem MA (2012). Comparative efficacy of different insecticides on sucking and chewing insect pests of cotton. Acad Res Int 3: 210.

39. Akbar MF, Haq MA \& Nikhat Y (2012). Effectiveness of bio-insecticides as compared to conventional insecticides against jassid (Amrasca devastans Dist.) on okra (Abelmoschus esculentus L.) crop. Pak Entomol 34: 161-165.

40. Ahmed S, Nisar MS, Shakir MM, Imran M \& Iqbal K (2014). Comparative efficacy of some neonicotinoids and traditional insecticides on sucking insect pests and their natural enemies on Bt-121 cotton crop. J Anim Plant Sci 24: 660-663.

41. Irshad M, Abbas G, Amer M, Khokhar MB, Ahmad M, Zakria M \& Khan GA (2015). Efficacy of different pesticides for the control of cotton jassid under the changing arid envirnoment of Thal zone. Int J Adv Res Biol Sci 2: 121-126.

42. Kadam DB, Kadam DR, Umate SM \& Lekurwale RS (2014). Bioefficacy of newer neonicotenoids against sucking insect pests of Bt cotton. Int J Plant Prot 7: 415-419. 